\title{
Description of two new Homoeocera Felder from Guatemala and Mexico (Lepidoptera, Arctiidae, Arctiinae, Euchromiini)
}

\author{
Michel Laguerre \\ 31 rue de la Haute-Lande, 33850 Léognan, France \\ urn:lsid:zoobank.org:author:2146C3FF-355D-4649-AB4B-20BE73BDC602 \\ Corresponding author: Michel Laguerre (mlaguerre@wanadoo.fr)
}

Academiceditor: ChristianSchmidt |Received 14September2009|Accepted23December2009|Published21 January2010

urn:lsid:zoobank.org:pub:D291A081-7B1B-4386-B5D3-5ECCF3B1077F

Citation: Laguerre M (2010) Description of two new Homoeocera Felder from Guatemala and Mexico (Lepidoptera, Arctiidae, Arctiinae, Euchromiini). ZooKeys 33: 29-38. doi: 10.3897/zookeys.33.275

\begin{abstract}
Two new species of Homoeocera Felder from Central America are described from high-altitude, humid localities in Mexico and Guatemala, Homoeocera georginas sp. n. and H. papalo sp. n. Both are compared to the closely related Homoeocera gigantea Druce. Illustrations of adults and male genitalia of the three species are provided. The generic placement within the genus Homoeocera is discussed.
\end{abstract}

\section{Keywords}

Euchromiini, Arctiidae, Neotropics, taxonomy, Homoeocera.

\section{Introduction}

The general classification of the Noctuoidea superfamily followed throughout this work is that of Mitchell et al. (2006) established on nuclear genes rather than the less traditionnal and more controversial classification proposed by Lafontaine and Fibiger (2006). At the tribe level the classification used follows the recent works of Kitching and Rawlins (1998) and Jacobson and Weller (2002).

In 2007, I had the opportunity to collect in Guatemala in very well preserved localities which gave a slight idea of the richness of this country around the end

Copyright M. Laguerre. This is an open access article distributed under the terms of the Creative Commons Attribution License, which permits unrestricted use, distribution, and reproduction in any medium, provided the original author and source are credited. 
of the $19^{\text {th }}$ century when the large work "Biologia Centrali-Americana" was written (Druce 1881-1890a). Even though Guatemala has been largely explored since 1850 , it is obvious that many new species of Lepidoptera are continually awaiting description.

During this trip, we spent two nights at Fuentes Georginas, Quetzaltenango, a high altitude $(2460 \mathrm{~m})$ locality with cold and very wet weather. We were surprised to find two different species of Homoeocera Felder in abundance: one larger species with wide black wing margins and clear transparent wings, and a second, smaller species with narrow black margins and yellowish transparent wings. Moreover, the smaller species displays conspicuous yellow intersegmental abdominal lines whereas the large one displays bright blue lines (Fig. 1).

The genus Homoeocera was created by Felder in 1874 for a single species, $H$. crassa Felder, 1874 (op. cit., Pl. 102, fig. 26) and for the moment contains between 8 and 24 species depending of the accepted limits of the genus (Draudt 1915; Global Lepidoptera Names Index website; Global Diversity Information facility website). The two species found in Guatemala are very similar to Homoeocera gigantea Druce, 1884, described in the first volume of "Biologia Centrali-Americana" (Druce 1884: 54, plate VIII fig. 5) based on a single female specimen from Costa Rica (Van Patten leg.). Later, in the second volume, Druce added two more localities: Guatemala from a specimen in Staudinger collection (Conradt leg.) and Guatemala City (Rodriguez leg.) (Druce 1897 p. 341). The holotype is in the general collection in BMNH in London (specimen examined). It is interesting to note that in addition to the type in the BMNH, there is a male from Guatemala bearing the label: Guatemala, Santa Maria, 5500', Sept, 1919-266.

Following this study it was clear that the two entities found in Guatemala represent two quite distinct species, the larger one having genitalia similar to Homoeocera gigantea from Costa Rica. Moreover it was also found that specimens from Oaxaca State in Mexico, also at high altitude, represent a new species different from the two species found in Guatemala. These two new species are described in the present work.

\section{Methods and materials}

Adult genitalia were prepared by boiling abdomens 15 minutes with 2 pellets of potash in $5 \mathrm{ml}$ of water. After rinsing with water and then alcohol, genitalia were photographed in a natural position suspended in $95 \%$ alcohol. Types and museum specimens were mounted in Euparal, and remaining specimens were stored in glycerol in Eppendorf tubes. Photos were taken with a CoolPix 4500 Nikkon camera attached to a trinocular Nikkon stereomicroscope SMZ-10A.

In order to check the exact distribution of each species, specimens were dissected from as many localities as possible. Specimens from the collection of Xavier Lesieur 
were included (Honduras and Mexico) and specimens originating from Mexico, Guatemala, Honduras and Costa Rica were dissected.

Three specimens each of $H$. gigantea and $H$. georginas were sequenced and analyzed using the barcode fragment of the mtDNA COI gene (BOLD: Barcode of Life Data Systems). DNA was extracted from legs of dried specimens in the collection of the author, then amplified and sequenced at the "Canadian Centre for DNA Barcoding" (CCDB) in Guelph, Ontario. Extraction, amplification and sequencing protocols can be found on the CCDB website (http://www.dnabarcoding.ca/pa/ge/research/protocols) and are also described in Vaglia et al. (2008).

Repository abbreviations are as follows:

BMNH The Natural History Museum (formerly British Museum [Natural History]), London.

DVUC Del Valle University, Guatemala City, Guatemala.

JMC Personal collection of José Monzon, Guatemala City, Guatemala.

MNHN Museum National d'Histoire Naturelle, Paris, France.

MLC Personal collection of Michel Laguerre, 33850 Léognan, France.

USNM National Museum of Natural History (formerly United States National Museum), Washington, D.C., USA.

XLC Personal collection of Xavier Lesieur, 95880 Enghien-les-Bains, France.

\section{Systematics}

Homoeocera gigantea Druce, 1884 In: Druce (1881-1890): 54 pl. VIII Fig. 5. Figs 2a, 2b, 3a-f

Diagnosis. Generally speaking a robust and handsome species well characterized by clear (not yellowish) transparent wings with black borders and crimson red legs. Most similar to $H$. georginas; see Diagnosis under that species.

Description. Head, collar, tegulae, thorax and antennae deep black. Abdomen above entirely black with bright blue intersegmental lines, difficult to see on dried specimens Forewing length $21-24 \mathrm{~mm}(\mathrm{n}=13)$. Forewings transparent and entirely bordered by a thin black line (around $0.3 \mathrm{~mm}$ ) with a small indentation on vein $\mathrm{CuA} 2$. Base of the wings largely black. Black line at the end of the cell reaching the costa. Hindwings reduced, entirely transparent, with termen bordered with a thin black line. Border wider along anal angle and with a small indentation just above the anal angle. The immediate basal area black.

The underside is almost identical to the upperside, palpi are entirely red; hindwings with a milky white iridescence just inside the anal border; all legs are crimson red except the tarsi which are dark-brown. There is a white depression at the base of the ventral abdomen in males. 


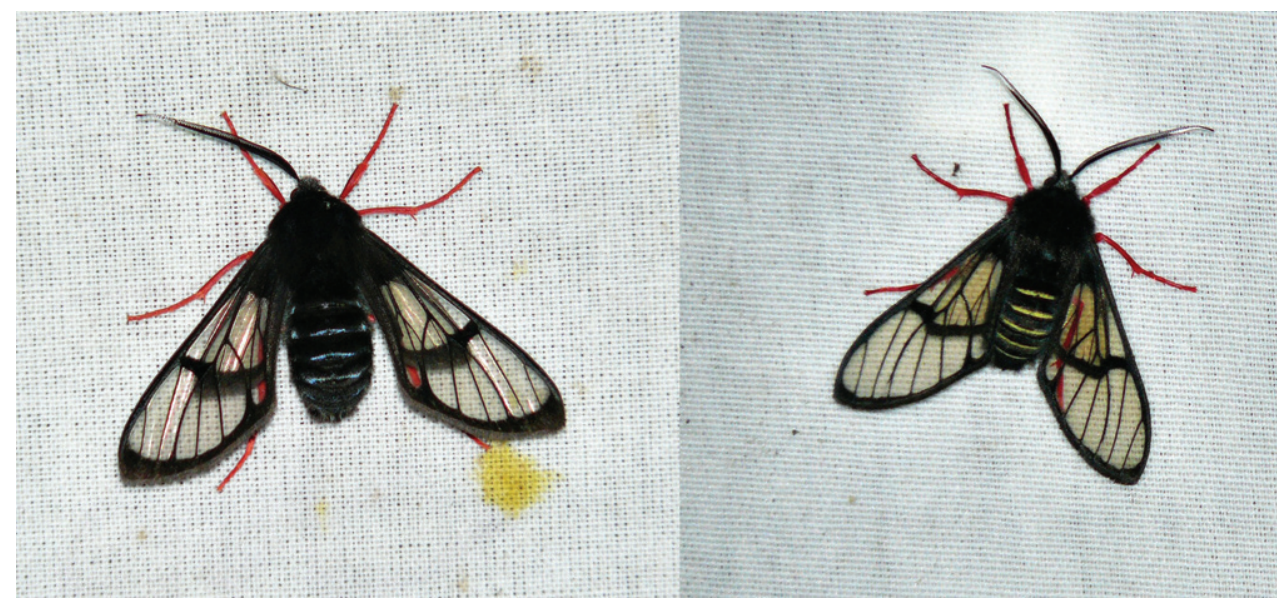

Figure I. Homoeocera gigantea (left) and Homoeocera georginas sp. n. (right) at rest, the same night, on the collecting sheet at Fuentes Georginas, Quetzaltenango, Guatemala (V. 2007).
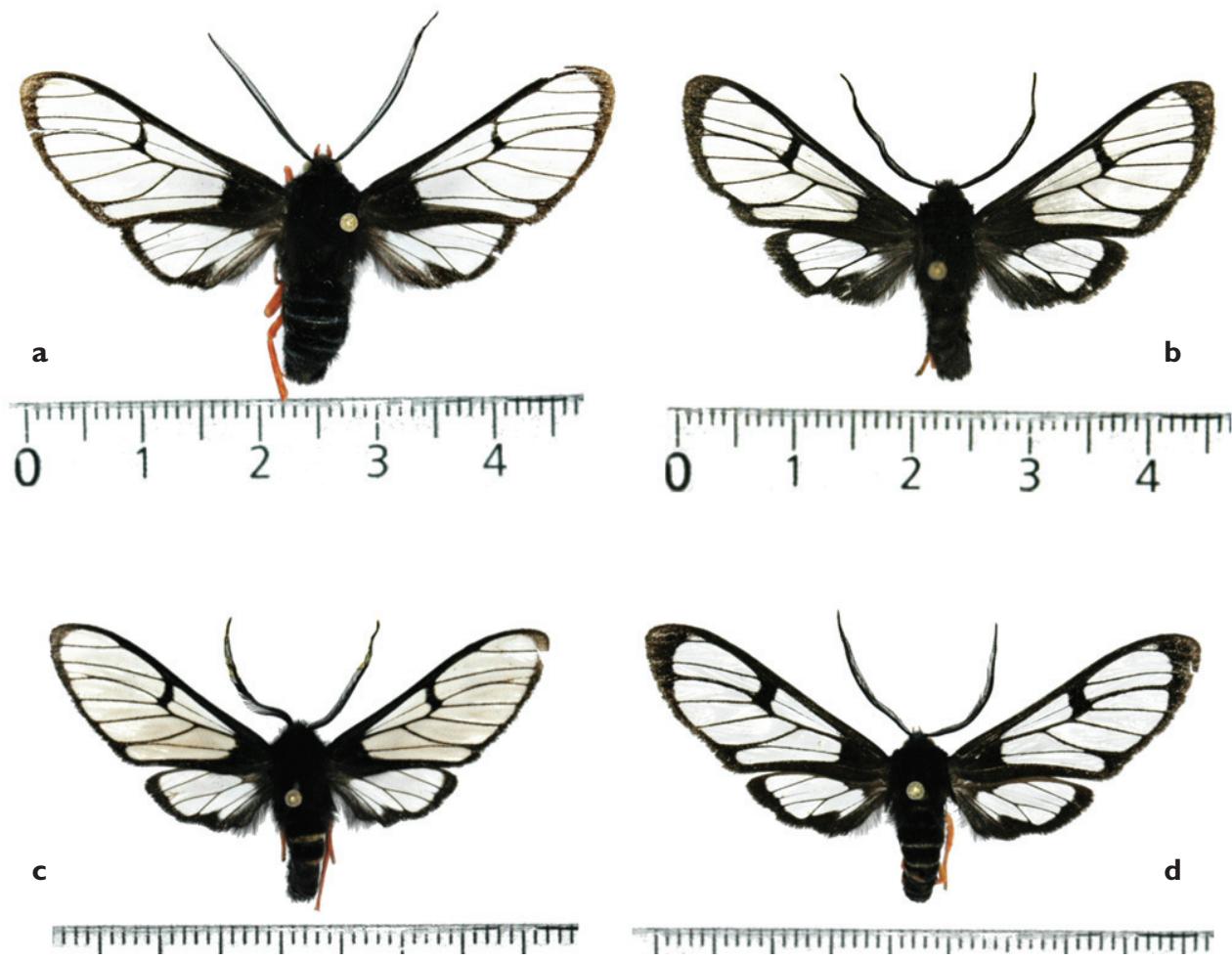

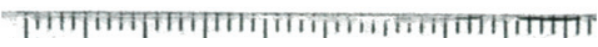

Figure 2. a Homoeocera gigantea, from Costa Rica, Cartago, Tapanti, X.1985 b Homoeocera gigantea from Guatemala, Quetzaltenango, Fuentes Georginas, 2460 m, 9.V. 2007, M. Laguerre leg. c Homoeocera georginas. nov., from Guatemala, Quetzaltenango, Fuentes Georginas, 2460 m, 9.V.2007, M. Laguerre leg. d Homoeocera papalo. nov., from Mexico, Oaxaca, Concepcion Papalo, 2275 m, 10.VII.1997, G. Nogueira leg. 


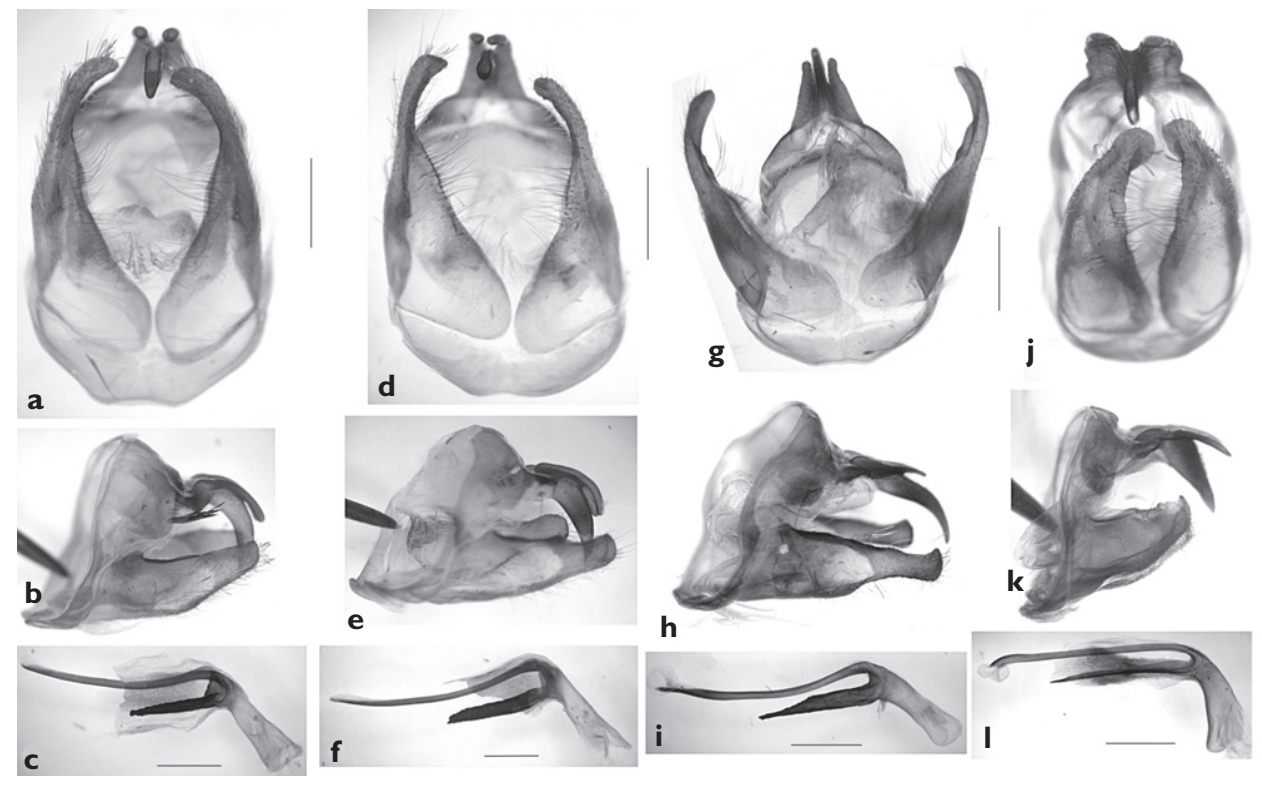

Figure 3. Homoeocera male genitalia with successively: ventral view, lateral view, penis in lateral view, all in natural positions for: a-c $H$. gigantea from Costa Rica $\mathbf{d}-\mathbf{f} H$. gigantea from Guatemala $\mathbf{g}-\mathbf{i} H$. georginas sp. n. from Guatemala j-I $H$. papalo sp. n. from Mexico. Scale bar $=1 \mathrm{~mm}$.

Specimens examined. GUATEMALA: Quetzaltenango, Fuentes Georginas, 11 \& 12.V.2007, $2460 \mathrm{~m}, 14^{\circ} 45.008 \mathrm{~N}-91^{\circ} 28.820 \mathrm{~W}$, M. Laguerre leg., 7 đ, one has been dissected Gen. ML1558, two have been bar-coded, GenBank accession numbers GU332713 (BOLD no. ARCTB327-08 / MILA0986) and GU332714 (ARCTB351-08 /MILA1010). All M. Laguerre leg. Zacapa, S.E. La Union, 15-V2007, $1400 \mathrm{~m}, 14^{\circ} 57.152 \mathrm{~N}^{\prime} 89^{\circ}$ 16.690' W, GenBank GU332715, BOLD no. ARCTA774-07 / MILA0493, M. Laguerre leg, 1 §. Suchitepéquez, Atitlan Reserve,

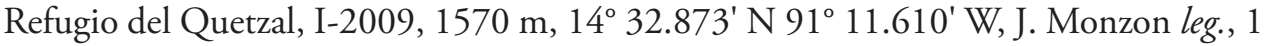
${ }^{7}$. San Marcos, Finca Esperanza, $1950 \mathrm{~m}, 30 . \mathrm{V} \&$ 1.VI.2008, $14^{\circ} 56^{\prime} 03.6^{\prime \prime} \mathrm{N}-91^{\circ}$ 51' 41.1" W, J. Touroult leg., 3 7 . [all in MLC]. HONDURAS: Prov. Morazan, 24 km NE Tegucigalpa, La Tigra, 1000 m, VI.1995, Porion / Lachaume leg., 3 §, one dissection \# Gen. ML1788 [XLC]. COSTA RICA: Cartago, Tapanti, X.1985, Gen. ML1678, 1 . COSTA RICA, San Jose, Cerro La Muerte, Paraiso del Quetzal, 2722 m, 14.IX.2009, $09^{\circ} 38^{\prime} 40.10^{\prime \prime} \mathrm{N}-83^{\circ}$ 51' 01.09" W, D. Herbin leg., 3 ○े [MLC].

Distribution and biology. As far as is known, H. gigantea is distributed from Guatemala to Costa Rica, generally at high altitude in very humid biotopes. It is not presently known from Nicaragua possibly because collecting at high altitude is difficult due to the topography of the country. The biology is unknown.

Remarks. Specimens from Guatemala and Honduras exhibit wider black wing borders compared to Costa Rican specimens, but the genitalia are similar. DNA barcode divergence between $H$. gigantea and $H$. georginas samples is approximately $3.8 \%$. 


\section{Homoeocera georginas Laguerre, sp. n.}

urn:lsid:zoobank.org:act:226C6379-FAC5-43CE-A280-61D3E5101C79

Figs $2 \mathrm{c}, 3 \mathrm{~g}-\mathrm{i}$

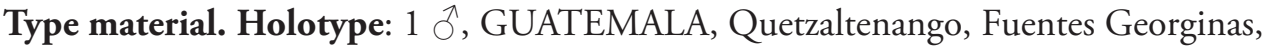
$11 \&$ 12.V.2007, $2460 \mathrm{~m}, 14^{\circ} 45.008 \mathrm{~N}-91^{\circ} 28.820 \mathrm{~W}, \mathrm{M}$. Laguerre leg. [printed white label] / Gen. ML1539 [hand-written white label] / MILA0966 [printed yellow label] / HOLOTYPE [printed red label]; GenBank accession no. GU332717, BOLD access code ARCTB307-08 / MILA0966 [MNHN]. PARATYPES (21 ð): GUATEMALA: same data as holotype, 9 , one has been dissected: Gen. ML1833, two specimens have been bar-coded, GenBank accession no. GU332716 (BOLD access codes ARCTB335-08 / MILA0994) and GU332718 (ARCTA791-07 / MILA0510, dissection Gen. ML1833), all M. Laguerre leg [MLC]. Same locality as holotype, 9 ${ }^{\lambda}$, 02.VII.2008, José Monzon leg., [JMC]; 1 đ̃, same locality as holotype but 27.IX.2006, Monzon, Heppner \& Sutton leg., [JMC]; 2 Oे, same locality as holotype but 24-25. VIII.2001, A. Bailey \& J. Monzon leg. [DVUC]. One paratype will be deposited in $\mathrm{BMNH}$ and USNM.

Etymology. The name is a reference to the type locality: Fuentes Georginas, a popular spot with hot springs high in the mountains on the Pacific slope.

Diagnosis. Similar to gigantea but less robust species with a yellow cast on forewings and very characteristic deep crimson red legs. By comparison $H$. gigantea is a larger and more robust species well characterized by the wider black margin of the fore- and hindwings. There is no yellowish cast on the forewings, the black indentation in space 2 of the hindwings is more pronounced, the abdomen upperside has a bluish hue with blue intersegmental lines (very difficult to see on dried specimens), the tip on the antennae below are not white, palpi are red not black.

In $H$. gigantea, the uncus is shorter and wider, the lateral protuberances are longer, wider and rounded (tapered in georginas) in lateral view, cylindrical in ventral view. The valvae are asymmetrical, the left one being slightly longer than the right one which reaches the base of uncus. The tegumen is a little wider, the concavity more pronounced and always without saccus. In the aedeagus, the ventral process is less than half the length of the upper process (greater than half in georginas), narrower but more sclerotized (almost black), and the apex of the ventral process is abruptly cut, not tapered as in georginas.

Description. Female unknown. Head, collar, tegulae, thorax and antennae deep black. Abdomen above entirely black with yellow intersegmental lines, difficult to see on dried specimens. Forewing length $18-20 \mathrm{~mm}(\mathrm{n}=10)$. Forewings transparent with a slight yellowish cast and entirely bordered by a thin black line (about $0.5 \mathrm{~mm}$ ) with a small indentation on vein $\mathrm{CuA} 2$. Base of the wings largely black. Black subrectangular spot at the end of the cell reaching the costa. Hindwings reduced, entirely transparent, with termen bordered with a thin black line but without the yellowish cast. Border wider along anal angle and with a small indentation just above the anal angle. The immediate basal area black. 
The underside is almost identical to the upperside, except the tip of the antennae which is white, palpi are entirely black, there is a milky white iridescence just inside the anal border on the hindwings and all legs are deep crimson red except the claws which are dark-brown.

Male Genitalia (Fig. 3g-i): Uncus long, pointed and curved downward, like a bird beak with a protuberance on each side. In lateral view these protuberances are very slender with a total length less than half the length of uncus. In ventral view, these protuberances have a rounded and almost cylindrical appearance. Valvae are symmetrical slighly curved inward and slightly spatulate at tip, reaching the middle of uncus. Tegumen slightly concave and without saccus. Adaegus very characteristic, divided into two distinct parts: an upper one, long, thin, slightly curved upwards and bearing a small smooth vesica and a lower part slightly longer than half the upper one, wider and strongly sclerotized, corrugated and with a bevelled extremity.

Distribution and biology. For the moment, known only for a restricted area in Guatemala, on the Pacific slope, at high altitude. Biology is unknown.

Remarks. Although sample size of barcoded specimens is small, the relatively large genetic divergence between gigantea and georginas, at about 3.8\%, fully support the recognition of these taxa as separate species.

\section{Homoeocera papalo Laguerre, sp. $\mathbf{n}$.}

urn:lsid:zoobank.org:act:FAD17F11-6571-4131-9297-03A3EDB2EDF5

Figs $2 \mathrm{~d}, 3 \mathrm{j}-1$

Type material. Holotype: $1 \hat{\jmath}$, MEXICO, Oaxaca, Concepcion Papalo, 2275 m, 10.VII.1997, G. Nogueira leg., (white printed label) / Gen. ML1672 (white handwritten label) / HOLOTYPE (red printed label) ; deposited in MNHN, Paris.

PARATYPES $(7 \hat{\jmath}): 1 \hat{\jmath}$, same data as holotype [MLC]. MEXICO: Oaxaca, Road Tuxtepec-Oaxaca, PK 86, 1750 m, VII.1992, J. Haxaire leg, 6 ふै, one dissected: Gen. ML1789. [XLC].

Etymology. The name is a reference to the type locality, Concepcion Papalo, a small city in north east Oaxaca state. The name Papalo means butterfly.

Diagnosis. Similar to gigantea but a less robust species with elongated forewings and orange red legs. H. papalo sp. n. is intermediate in size between gigantea and georginas, but the forewings are obviously narrower and elongated. There is no yellowish cast on the forewings as in georginas, however the underside tip of antennae is white as in georginas. Palpi and legs are orange not deep crimson red as in georginas and gigantea. The genitalia of $H$. papalo are also very distinct from the two other species. Here, the lateral protuberances of the uncus have a very different shape, the symmetrical valvae are very short, not reaching the base of uncus. The adaegus has two long lobes of similar length, whereas the lobes are very obviously of different lengths in gigantea and georginas.

Description. Female unknown. Head, collar, tegulae, thorax and antennae deep black. The collar displays a metallic bright blue cast. Abdomen deep black upperside 
with bright line at the end of segments. Forewing length $20-21 \mathrm{~mm}(\mathrm{n}=2)$. Forewings elongated, transparent, entirely bordered by a black line wider than in $H$. georginas sp. n. specially at apex where it is enlarged and presence of a small indentation on vein $\mathrm{CuA2}$. Base of wings is largely black, the subrectangular cellular spot at the end of the cell is large and conspicuous. Hindwings transparent, black border wide except on costa with an indentation on vein $\mathrm{CuA} 2$. The extreme base black. Underside similar to upperside, tip of the antennae white, palpi and legs orange. A milky white iridescence just inside the anal border on the hindwings.

Male Genitalia (Fig. 3 j-l). Uncus conical, stout and pointed, with a protuberance on each side. In lateral view these protuberances are very slender with a total length exceeding half the length of uncus. In ventral view, these protuberances are semi-circular not unlike "ears". Valvae are symmetrical, slighly curved inward and spatulate at tip, not reaching the base of uncus. Tegumen rounded and without saccus. Adaegus very characteristic, divided into two distinct parts: a dorsal long, thin, rectilinear process with the apex slightly curved downward and bearing a small smooth vesica and a ventral thin, pointed process reaching about $3 / 4$ length of the dorsal one.

Distribution and biology. Currently known only from a very restricted area in Oaxaca state in Mexico, at high altitude. The biology is unknown.

\section{Discussion}

The three species discussed here constitute a very homogeneous group in both habitus and genitalia. This study adds data to the BOLD project, which aims to build a DNA barcode database of all macrolepidoptera (Hebert et al. 2003), and a campaign targeting the neotropical Arctiidae has been initiated. To date, more than 2200 sequences accounting for about 750 species (i.e., more than $10 \%$ of currently described neotropical Arctiidae) from at least 16 countries have been analyzed.

The main problem in Homoeocera seems to be the correct generic assignment of this group of species. When he described gigantea, Druce included this species within the genus Gymnelia Walker near torquata Druce, which he had described sometime earlier (Druce 1883). In 1898, Hampson transferred gigantea to Homoeocera Felder whereas in 1914 he transferred torquata to Dassysphinx Felder. What is clear from dissection of the generotype of Homoeocera (i.e. crassa Felder) is that the three above species are not congeneric with crassa. Furthermore, based on the habitus, torquata seems misplaced within the genus Dassysphinx, but together with the three species treated here, tarsipuncta Schaus, garleppi Rothschild and ockendeni Rothschild (all three presently included within Dassysphinx) seem to constitute a rather homogeneous group. A correct generic assignment of all these species requires a complete revision of the genus Homoeocera, which is far beyond the scope of this work. It seems prudent at the moment to maintain the status quo and assign the two new species to the genus Homoeocera. 


\section{Acknowledgements}

I acknowledge my friend and colleague Xavier Lesieur for giving me access to several series of Homoeocera from his collection, and special thanks to Jack Schuster at Universidad del Valle and CONAP for obtaining collecting permits.

I would also like to acknowledge Paul Hebert (CCDB, Guelph, Canada) for access to the BOLD project and providing very efficient, competent and quick DNA barcoding, and Rodolphe Rougerie (Biodiversity Institute of Ontario, University of Guelph, Ontario, Canada) for his help and his technical and scientific support in editing and compiling the hundreds of various sequences involved in the ARCT project. Finally, thanks to an anonymous reviewer for greatly improving the grammar and English of this work.

\section{References}

Barcode of Life Data Systems. Campaign: Lepidoptera of Area de Conservacion Guanacaste (ACG). http://www.lepbarcoding.org/cl_acg.php [accessed X 2009].

Draudt M (1915) In: Seitz A (1915-1925) Die Gross-Schmetterlinge der Erde, 6, Stuttgart.

Druce H (1881-1890a) Biologia Centrali-Americana, Insecta Lepidoptera-Heterocera, Vol. I:

(text). Porter RH Publishers, London, 490 pp.

Druce H (1881-1890b) Biologia Centrali-Americana, Insecta Lepidoptera-Heterocera, Vol. III (Plates). Porter RH Publishers, London, 101 plates.

Druce H (1883) Descriptions of new species of Zygaenidae and Arctiidae. Proceedings of the Zoological Society of London: 372-384.

Druce H (1891-1900) Biologia Centrali-Americana, Insecta Lepidoptera-Heterocera, Vol. II: (text). Porter RH Publishers, London, 622 pp.

Felder C, Felder R, Rogenhofer AF (1874-1875) Lepidoptera. In: Kaiserlichen Akademie der Wissenschaften (Ed), Reise der Österreichischen Fregatte Novara um die Erde in den Jahren 1857, 1858, 1859 unter den Befehlen des Commodore B. von Wüllersortf-Urbair, Zoologischer Theil, Zweiter Band, Zweite Abtheilung, Band 2. Wien, Carl Gerold's Sohn. pp. 1-9+1-10+1-20, pls 1-140.

Global Lepidoptera Names Index. http:/www.nhm.ac.uk/jdsml/research-curation/research/ projects/lepindex/index.dsml [accessed Sep. 2009].

Global Biodiversity Information Facility. http:/www.gbif.net/species/browse/provider/1/taxon/13143276/ [accessed Sep. 2009].

Hampson GF (1898) Catalogue of the Lepidoptera Phalaenae in the British Museum. Vol. 1. British Museum (Natural History), London, XXI + 559 pp.

Hampson GF (1914) Catalogue of the Lepidoptera Phalaenae in the British Museum. Suppl. Vol. 1. British Museum (Natural History), XXVIII + 858 pp.

Hebert PDN, Cywinska A, Ball SL, deWaard JR (2003) Biological identifications through DNA barcodes. Proceedings of the Royal Society of London B 270 : 313-321. 
Jacobson NL, Weller SJ (2002) A cladistic study of the tiger moth family Arctiidae (Noctuoidea) based on larval and adult morphology. Thomas Say Monograph Series, Ent. Soc. America, 98pp.

Kitching IJ, Rawlins JE (1999 [1998]) The Noctuoidea. In: Kristensen, NP (Ed) Lepidoptera, Moths and Butterflies Volume 1: Evolution, Systematics and Biogeography. Handbook of Zoology IV (35). Berlin and New York: Walter de Gruyter, 355-401

Lafontaine JD, Fibiger M (2006) Revised higher classification of the Noctuoidea (Lepidoptera). Canadian entomologist, 138 (5): 610-635.

Mitchell A, Mitter C, Regier JC (2006) Sytematics and evolution of the cutworm moths (Lepidoptera: Noctuidae): evidence from two protein-coding nuclear genes. Systematic Entomology, 31: 21-46.

Vaglia T, Haxaire J, Kitching IJ, Meusnier I, Rougerie R (2008) Morphology and DNA barcoding reveal three cryptic species within the Xylophanes neoptolemus and loelia speciesgroups (Lepidoptera: Sphingidae). Zootaxa, 1923: 18-36. 